\title{
PENGARUH HUTAN KOTA TERHADAP REDUKSI KEBISINGAN LALU LINTAS DI JALAN A. YANI PONTIANAK (STUDI KASUS ARBORETUM SYLVA UNTAN DAN HALAMAN KANTOR GUBERNUR KALBAR)
}

\author{
Dini Wahyu Sondag Ginting ${ }^{1}$, Syafaruddin $\mathrm{AS}^{2}$, Sarma Siahaan ${ }^{3}$ \\ ${ }^{1}$ Program Studi Teknik Lingkungan, Universitas Tanjungpura, Pontianak \\ ${ }^{2}$ Program Studi Teknik Sipil, Universitas Tanjungpura, Pontianak \\ ${ }^{3}$ Program Studi Kehutanan, Universitas Tanjungpura, Pontianak \\ email : diniwahyusg@gmail.com
}

\begin{abstract}
ABSTRAK
Kawasan Jalan A. Yani Pontianak merupakan salah satu jaringan jalan dengan aktivitas transportasi yang tinggi. Hal ini menyebabkan terjadinya perubahan kualitas fisik lingkungan yaitu timbulnya kebisingan. Arboretum Sylva Untan di tengah kota Pontianak menjadi solusi untuk memperbaiki kualitas fisik lingkungan salah satunya sebagai peredam kebisingan. Tujuan dari penelitian ini adalah mengetahui tingkat kebisingan di Arboretum Sylva Untan dan di halaman kantor Gubernur Kalbar (kontrol), mengetahui kemampuan Arboretum Sylva Untan mereduksi tingkat kebisingan lalu lintas di Jalan A. Yani, dan menganalisis tingkat kebisingan di kawasan jalan A. Yani dikaitkan dengan baku tingkat kebisingan menurut Keputusan Menteri Negara Lingkungan Hidup No.48 tahun 1996. Pengukuran kebisingan dilakukan pada pukul 06.00-08.00 WIB dengan empat kali pengulangan disertai pengukuran kondisi lingkungan dan kondisi lalu lintas. Berdasarkan hasil analisa, Arboretum Sylva Untan pada jarak 2-50m dari sumber suara, dengan jumlah vegetasi 449 jenis, mampu mereduksi tingkat kebisingan sebesar $16,29 \mathrm{~dB}$ atau $21 \%$ dan pada jarak $50-98 \mathrm{~m}$ dari sumber suara, dengan jumlah vegetasi 317 jenis mereduksi tingkat kebisingan sebesar $7,61 \mathrm{~dB}$ atau $12,44 \%$. Berdasarkan data tersebut, maka kemampuan reduksi Arboretum Sylva Untan dengan area pengukuran $180 \mathrm{~m} \times 96 \mathrm{~m}$ dengan jumlah vegetasi 716 jenis, mampu mereduksi tingkat kebisingan sebesar $23,90 \mathrm{~dB}$ atau $44,86 \%$. Dengan kemampuan reduksi tersebut, menjadikan kawasan Universitas Tanjungpura memenuhi standar baku tingkat kebisingan untuk kawasan pendidikan, yaitu 55dB. Dan pada lokasi halaman kantor Gubernur Kalbar dengan kemampuan reduksi tingkat kebisingan sebesar $16,85 \mathrm{~dB}$ menjadikan kawasan kantor Gubernur Kalbar memenuhi standar baku tingkat kebisingan untuk kawasan fasilitas umum dan pemerintahan, yaitu 60dB.
\end{abstract}

Kata kunci : Arboretum Sylva Untan, kebisingan, vegetasi

\begin{abstract}
A. Yani Pontianak Street is one of the road with higher transportation activity. This case leads to changes in the physical quality of the environment, increase of noise. Arboretum Sylva Untan located in the center of Pontianak city, can be a solution to improve the physical quality of the environment as a noise reducer. The purpose of this research is to determined the level of noise in Arboretum Sylva Untan and in the office of Governor of West Kalimantan yard (control), determined the ability Arboretum Sylva Untan to reduce traffic noise levels at A. Yani street, and analyzed the noise level in the area of A. Yani street refering to the Decree of the Minister of Environment of Republic of 48 of 1996. Noise levels have been measured start at 06.00 am until 08.00 am with four repetitions along with environment conditions and traffic conditions. Based of analysis results, Arboretum Sylva Untan at a distance of 2-50 meters from the sound source, with 449 types of vegetation can reduce noise level $16,29 \mathrm{~dB}$ or $21 \%$ and at a distance of 50-98 meters from the sound source, with 317 types of vegetation can reduce noise level $7,61 \mathrm{~dB}$ or $12,44 \%$. Based on these, Arboretum Sylva Untan with measurements area $180 \mathrm{~m} \times 96 \mathrm{~m}$, with 716 types of vegetation can reduce noise level $23,90 \mathrm{~dB}$ or $44,86 \%$. With the reduction ability, make the Tanjungpura University area accord to standard permitted for education areas is $55 \mathrm{~dB}$. And in the office of Governor of West Kalimantan yard with the reduction ability 16,85 dB make the office of Governor of West Kalimantan accord to standard permitted for public facility and government areas is $60 \mathrm{~dB}$.

Keyword: Arboretum Sylva Untan, noise level, vegetation.
\end{abstract}




\section{PENDAHULUAN}

Jalan A. Yani Pontianak merupakan salah satu jalan utama di kota Pontianak. Pemanfaatan lahan di sepanjang jalan A. Yani telah mengalami peningkatan seiring perkembangan ekonomi. Banyak lokasi yang berubah pola pemanfaatan lahannya dari kawasan perkantoran menjadi kawasan perdagangan dan jasa. Jalan A. Yani merupakan akses utama untuk menuju pusat kota dimana jalan tersebut menjadi penghubung untuk menuju pada kawasan pendidikan, perkantoran, perdagangan dan jasa, dan sebagainya sehingga berpengaruh pada banyaknya jumlah kendaraan yang melintasi jalan ini.

Aktivitas transportasi yang memiliki pengaruh besar terhadap kebisingan adalah kendaraan bermotor. Kebisingan akibat aktivitas transportasi bersumber dari suara yang dihasilkan dari kendaraan bermotor, terutama dari mesin kendaraan, knalpot, serta akibat interaksi antara roda dengan jalan. Kebisingan merupakan bentuk suara yang tidak dikehendaki karena dianggap mengganggu.

Arboretum Sylva Untan merupakan salah satu kawasan penyangga di tengah - tengah perkotaan kota Pontianak. Tanaman dapat berperan dalam pengendalian kebisingan karena dapat menyerap dan memencarkan energi bunyi. Oleh karena itu, akan dilakukan suatu penelitian mengenai kemampuan reduksi kebisingan lalu lintas di jalan A. Yani Pontianak oleh vegetasi di Arboretum Sylva Untan.

\section{METODE PENELITIAN}

Penelitian ini dilaksanakan di kota Pontianak, Provinsi Kalimantan Barat, berlokasi Arboretum Sylva Untan dan di halaman kantor Gubernur Provinsi Kalbar. Waktu pengukuran ditentukan berdasarkan hasil dari survey pendahuluan.

a. Survei Pendahuluan. Dilakukan pengukuran volume dan kecepatan kendaraan yang melintas di jalan A. Yani, yaitu arah bundaran Untan ke kantor Gubernur Kalbar dan sebaliknya. Waktu pengukuran kondisi lalu lintas, yaitu pagi (06.00-08.00), siang (11.0013.00), dan sore (16.00 - 18.00) dengan pencatatan waktu dalam selang 10 menit. Pengukuran dilakukan pada hari Senin, Selasa, Sabtu, dan Minggu.

b. Pengukuran Kebisingan. Pengukuran kebisingan dilakukan sesuai arahan KepMenLH Nomor 48/MENLH/1996, yaitu dengan cara sederhana selama 20 menit dengan waktu pengukuran pada pukul $06.40-07.00$ di plot I, pukul $07.10-07.30$ di plot II, dan pukul $07.40-08.00$ di plot III dengan menggunakan alat sound level meter (SLM).

c. Pengukuran kondisi lingkungan yaitu pengukuran suhu udara, kecepatan dan arah angin.
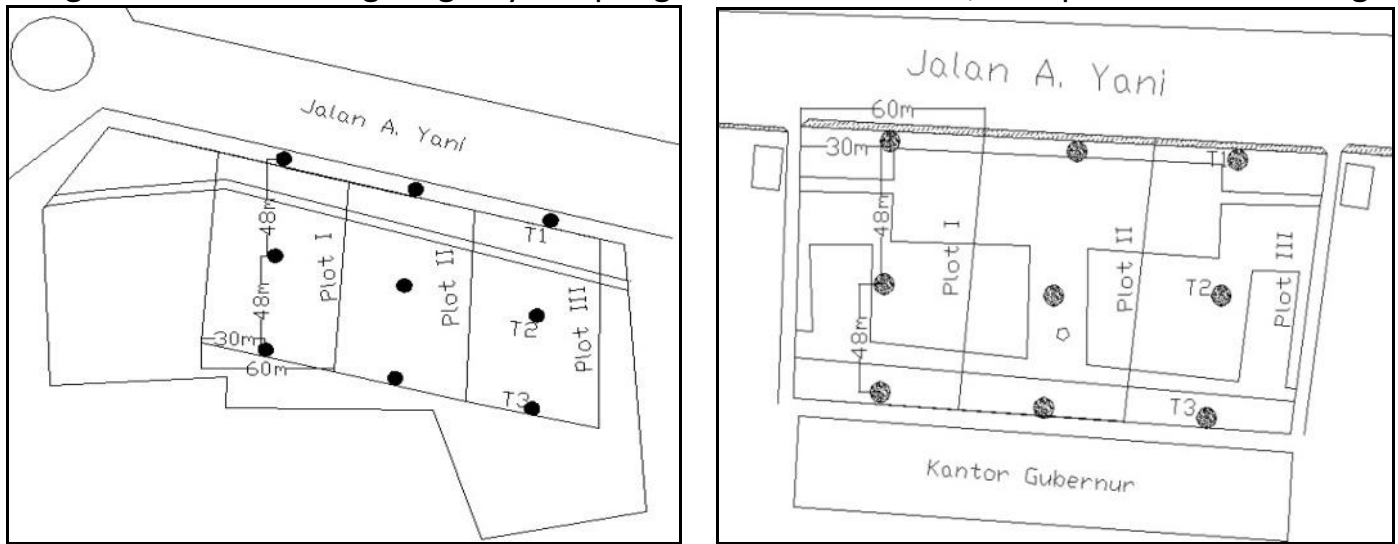

(a)Arboretum Sylva Untan

(b) Halaman Kantor Gubernur Kalbar

Gambar 1. Lokasi Pengukuran 


\section{HASIL DAN ANALISA}

\section{A. PENGUKURAN TINGKAT KEBISINGAN}

Survei pendahuluan dilakukan pada hari Sabtu, 19 Oktober 2013 - Selasa, 22 Oktober 2013. Berdasarkan hasil analisa, jam puncak kendaraan yang melintas di ruas jalan A. Yani, yaitu pada hari Senin pukul 06.00-08.00, dengan volume kendaraan terpadat yang melintas dimulai pada pukul 06.40 , sehingga waktu pengukuran tingkat kebisingan akan dilakukan pada hari Senin pukul 06.00-08.00 dengan 4 kali pengulangan. Data volume lalu lintas dalam satuam unit di ruas Jalan A. Yani Pontianak, Senin 21 Oktober 2013 disajikan pada Tabel 1.

Tabel 1. Volume Lalu Lintas (Unit) Ruas Jalan A. Yani Pontianak, Senin 21 Oktober 2013

\begin{tabular}{|c|c|c|c|c|c|c|c|c|}
\hline \multirow{2}{*}{ Waktu } & \multicolumn{3}{|c|}{ Kantor Gubernur - Bundaran Untan } & \multicolumn{4}{|c|}{ Bundaran Untan - Kantor Gubernur } \\
\cline { 2 - 9 } & MC & LV & HV & Jumlah & MC & LV & HV & Jumlah \\
\hline 06.10 & 973 & 289 & 1 & 1263 & 436 & 190 & 0 & 626 \\
\hline 06.20 & 1210 & 149 & 1 & 1360 & 527 & 206 & 3 & 736 \\
\hline 06.30 & 1322 & 100 & 1 & 1423 & 694 & 272 & 8 & 974 \\
\hline 06.40 & 1788 & 293 & 0 & 2081 & 887 & 256 & 0 & 1143 \\
\hline 06.50 & 2130 & 616 & 0 & 2746 & 754 & 169 & 2 & 925 \\
\hline 07.00 & 1165 & 289 & 2 & 1456 & 850 & 195 & 1 & 1046 \\
\hline 07.10 & 1149 & 205 & 0 & 1354 & 1030 & 193 & 4 & 1227 \\
\hline 07.20 & 971 & 165 & 1 & 1137 & 1023 & 163 & 1 & 1187 \\
\hline 07.30 & 2196 & 202 & 1 & 2399 & 899 & 192 & 1 & 1092 \\
\hline 07.40 & 1152 & 181 & 7 & 1340 & 1202 & 171 & 4 & 1377 \\
\hline 07.50 & 1095 & 196 & 4 & 1295 & 1123 & 175 & 7 & 1305 \\
\hline 08.00 & 956 & 173 & 8 & 1137 & 918 & 204 & 15 & 1137 \\
\hline Total & 16107 & 2858 & 26 & 18991 & 10343 & 2386 & 46 & 12775 \\
\hline
\end{tabular}

Tingkat kebisingan ekuivalen (Leq) merupakan model yang dipergunakan untuk menyatakan tingkat kebisingan yang merupakan tingkat tekanan suara rerata dalam selang waktu tertentu. Rumus yang digunakan untuk menentukan Leq adalah (Pusat Pendidikan dan Pelatihan MenLH, 2009) :

$$
\text { Leq }=10 \log \frac{1}{120} \Sigma 10^{0,1 \cdot 17 \mathrm{~dB}}
$$

keterangan :

$\mathrm{L}_{\mathrm{eq}}=$ nilai tingkat kebisingan dari kebisingan yang berubah-ubah (fluktuatif) selama waktu tertentu, yang setara dengan tingkat kebisingan dari kebisingan yang steady pada waktu yang sama, pada interval antara jam i dan jam j,

$\mathrm{I}_{\mathrm{i}}=$ level pada data ke-i.

\section{Hasil dan Analisa Perhitungan Tingkat Kebisingan di Arboretum Sylva Untan}

Rata-rata nilai Leq di Arboretum Sylva Untan berdasarkan empat kali pengukuran disajikan dalam Tabel 2.

Tabel 2. Rata - rata Tingkat Kebisingan (Leq) di Arboretum Sylva Untan

\begin{tabular}{|c|c|c|c|c|c|c|}
\hline \multirow{2}{*}{ Plot } & Titik & $\begin{array}{c}\text { Leq (dB) } \\
\text { 25 Nov 2013 }\end{array}$ & $\begin{array}{c}\text { Leq (dB) } \\
\text { 2 Des 2013 }\end{array}$ & $\begin{array}{c}\text { Leq (dB) } \\
\text { 16 Des 2013 }\end{array}$ & $\begin{array}{c}\text { Leq (dB) } \\
\text { 22 Mei 2014 }\end{array}$ & $\begin{array}{c}\text { Rata-rata } \\
(\mathrm{dB})\end{array}$ \\
\hline \multirow{3}{*}{ Plot I } & Titik 1 & 75,55 & 78,10 & 76,71 & 75,11 & 76,37 \\
\cline { 2 - 7 } & Titik 2 & 61,03 & 63,27 & 62,42 & 58,03 & 61,19 \\
\cline { 2 - 7 } & Titik 3 & 52,52 & 57,43 & 50,42 & 49,57 & 52,48 \\
\hline \multirow{3}{*}{ Plot II } & Titik 1 & 75,72 & 81,44 & 79,72 & 75,26 & 78,03 \\
\cline { 2 - 7 } & Titik 2 & 61,51 & 62,54 & 62,76 & 58,88 & 61,42 \\
\cline { 2 - 7 } & Titik 3 & 54,62 & 58,33 & 53,33 & 50,11 & 54,10 \\
\hline \multirow{3}{*}{ Plot III } & Titik 1 & 76,47 & 80,79 & 80,42 & 75,42 & 78,27 \\
\cline { 2 - 7 } & Titik 2 & 61,49 & 61,74 & 63,25 & 58,31 & 61,20 \\
\cline { 2 - 7 } & Titik 3 & 56,36 & 58,16 & 53,23 & 49,89 & 54,41 \\
\hline
\end{tabular}


Tingkat kebisingan berkisar antara 76,37 dB-78,27 dB di titik 1, dapat diterima oleh pendengar selama $\pm 12-14$ jam. Pada lokasi ini, kendaraan dari arah kantor gubernur menuju bundaran Untan yang melintas di depan Arboretum umumnya menurunkan kecepatan kendaraannya dikarenakan adanya lampu lalu lintas. Efek dari penurunan kecepatan kendaraan ini dapat dilihat dari nilai Leq pada titik 1 plot I di Arboretum, yaitu sebesar 76,37 $\mathrm{dB}$, dimana titik ini berjarak \pm 80 meter dari lampu lalu lintas dan banyak kendaraan berjalan dalam kondisi lambat bahkan diam. Nilai Leq di titik 1 plot I ini lebih kecil dibanding dengan Leq titik 1 pada plot II dan III yang berjarak \pm 140 meter dan \pm 200 meter dari lampu lalu lintas karena kendaraan umumnya berjalan dengan kecepatan normal dan baru mulai menurunkan kecepatan.

Lokasi pengukuran di Arboretum Arboretum Sylva Untan dekat dengan perempatan jalan tingkat kebisingannya dipengaruhi oleh adanya penumpukan kendaraan di sekitar wilayah tersebut. Selain itu, lokasi pengukuran yang berada dekat dengan lampu lalu lintas (ruas jalan A. Yani arah Kantor Gubernur menuju bundaraan Untan), sehingga kendaraan dominan berada pada kondisi diam dan mengalami kemacetan hingga $\pm 350 \mathrm{~m}$ dari lampu lalu lintas. Pada saat kepadatan jumlah kendaraan tinggi, dimana kecepatan kendaraan rendah, bunyi yang dihasilkan berasal dari klakson kendaraan dan pengereman (Arlan, 2011).

\section{Hasil dan Analisa Perhitungan Tingkat Kebisingan di Halaman Kantor Gubernur Kalbar}

Rata-rata nilai Leq di halaman kantor Gubernur Kalbar berdasarkan empat kali pengukuran disajikan dalam Tabel 3.

Tabel 3. Rata - rata Tingkat Kebisingan (Leq) di Halaman Kantor Gubernur Kalbar

\begin{tabular}{|c|c|c|c|c|c|c|}
\hline \multirow{2}{*}{ Plot } & Titik & $\begin{array}{c}\text { Leq (dB) } \\
\text { 25 Nov 2013 }\end{array}$ & $\begin{array}{c}\text { Leq (dB) } \\
\text { 2 Des 2013 }\end{array}$ & $\begin{array}{c}\text { Leq (dB) } \\
\text { 16 Des 2013 }\end{array}$ & $\begin{array}{c}\text { Leq (dB) } \\
\text { 21 Mei 2014 }\end{array}$ & $\begin{array}{c}\text { Rata-rata } \\
\text { (dB) }\end{array}$ \\
\hline \multirow{3}{*}{ Plot I } & Titik 1 & 79,63 & 79,26 & 78,42 & 75,12 & 78,11 \\
\cline { 2 - 7 } & Titik 2 & 63,30 & 66,31 & 61,95 & 63,10 & 63,67 \\
\cline { 2 - 7 } & Titik 3 & 61,35 & 60,53 & 59,84 & 59,43 & 60,28 \\
\hline \multirow{3}{*}{ Plot II } & Titik 1 & 80,42 & 77,06 & 78,33 & 75,46 & 77,82 \\
\cline { 2 - 7 } & Titik 2 & 63,05 & 69,31 & 61,76 & 64,69 & 64,70 \\
\cline { 2 - 7 } & Titik 3 & 62,05 & 62,54 & 60,50 & 62,89 & 61,99 \\
\hline \multirow{3}{*}{ Plot IIII } & Titik 1 & 77,62 & 78,89 & 79,69 & 74,96 & 77,79 \\
\cline { 2 - 7 } & Titik 2 & 62,16 & 67,98 & 63,10 & 62,88 & 64,03 \\
\cline { 2 - 7 } & Titik 3 & 60,75 & 61,28 & 61,49 & 59,99 & 60,87 \\
\hline
\end{tabular}

Tingkat kebisingan sebesar berkisar antara 77,79 - 78,11 dB di titik 1, dapat diterima oleh pendengar selama $\pm 12-14$ jam. Kendaraan yang melewati kantor gubernur dari arah A. Yani II menuju bundaran Untan dan sebaliknya, umumnya melintas dengan kecepatan tinggi karena kondisi kedua ruas jalan yang lancar serta tidak terdapat penghalang (simpang atau lampu lalu lintas) yang dapat membatasi laju kendaraan. Kondisi lalu lintas seperti ini menyebabkan tingkat kebisingan di lokasi ini cukup tinggi. Pada saat kecepatan tinggi, bunyi yang ditimbulkan berasal dari bunyi knalpot dan bunyi mesin kendaraan (Arlan, 2011).

Halaman kantor gubernur hanya ditumbuhi oleh rumput teki, tanaman perdu, dan tanaman jenis pohon, pohon pinang. Hal ini mengakibatkan tingkat kebisingan pada lokasi ini lebih tinggi karena tidak adanya penghalang suara/bunyi.

\section{B. ANALISA KONDISI LALU LINTAS TERHADAP TINGKAT KEBISINGAN}

\section{Hasil dan Analisa Volume Kendaraan}

Aktivitas transportasi yang memiliki pengaruh besar terhadap kebisingan adalah keberadaan kendaraan bermotor. Kendaraan bermotor memberikan pengaruhnya melalui 
suara yang dihasilkan kendaraan tersebut dari knalpotnya. Pada saat tertentu, motor yang memiliki knalpot yang sudah tidak standar menghasilkan kebisingan yang sangat besar. Suara knalpot dari sepeda motor yang telah di modifikasi yang dapat mencapai 80 - 90 dBA (Krisindarto dalam Widyantoro dan Razif, 2013). Rata - rata volume kendaraan (smp) di ruas Jalan A. Yani Pontianak berdasarkan empat kali pengukuran disajikan dalam Tabel 4.

Tabel 4. Rata - rata Volume Kendaraan (smp) di Ruas Jalan A. Yani Pontianak

\begin{tabular}{|c|c|c|c|c|c|}
\hline Waktu & 25 Nov 2013 & 02 Des 2013 & 16 Des 2013 & 21 Mei 2014 & Rata-rata \\
\hline $06.00-06.10$ & 598 & 647 & 528 & 413 & 547 \\
\hline $06.10-06.20$ & 762 & 918 & 598 & 594 & 718 \\
\hline $06.20-06.30$ & 1245 & 1250 & 877 & 948 & 1080 \\
\hline $06.30-06.40$ & 1421 & 1598 & 1203 & 1224 & 1362 \\
\hline $06.40-06.50$ & 1491 & 1524 & 1407 & 1421 & 1461 \\
\hline $06.50-07.00$ & 1486 & 1410 & 1427 & 1410 & 1433 \\
\hline $07.00-07.10$ & 1440 & 1530 & 1676 & 1510 & 1539 \\
\hline $07.10-07.20$ & 1465 & 1805 & 1464 & 1492 & 1556 \\
\hline $07.20-07.30$ & 1529 & 1753 & 1480 & 1511 & 1568 \\
\hline $07.30-07.40$ & 1539 & 1415 & 1492 & 1532 & 1494 \\
\hline $07.40-07.50$ & 1553 & 1782 & 1657 & 1475 & 1617 \\
\hline $07.50-08.00$ & 1652 & 1578 & 1563 & 1489 & 1571 \\
\hline
\end{tabular}

Berdasarkan empat kali pengukuran, rata-rata kendaraan terpadat yang melintas di jalan A. Yani Pontianak volume kendaraan tertinggi yaitu sebesar $1617 \mathrm{smp}$ dan terendah yaitu 547 smp.

Hasil dan Analisa Pengukuran Kecepatan Lalu Lintas

Rata-rata kecepatan lalu lintas di Jalan A. Yani Pontianak disajikan dalam Tabel 5.

Tabel 5. Rata - rata Kecepatan Lalu Lintas $(\mathrm{Km} / \mathrm{jam})$ di Ruas Jalan A. Yani Pontianak, Senin Pukul $06.00-08.00$

\begin{tabular}{|c|c|c|c|c|c|}
\hline \multicolumn{3}{|c|}{ Sisi Kiri } & \multicolumn{3}{c|}{ Sisi Kanan } \\
\hline MC & LV & HV & MC & LV & HV \\
\hline 68,69 & 62,78 & 55,49 & 70,94 & 67,48 & 62,23 \\
\hline
\end{tabular}

Berdasarkan hasil analisa, terlihat bahwa faktor kecepatan berpengaruh terhadap tingkat kebisingan. Menurut Handayani (2003), kecepatan kendaraan diatas 40 km/jam cukup potensial untuk membangkitkan kebisingan.

\section{ANALISA HUBUNGAN JARAK PENGUKURAN TERHADAP TINGKAT KEBISINGAN}

Analisa yang digunakan untuk mengetahui hubungan (korelasi) antara jarak pengukuran dengan tingkat kebisingan adalah dengan menggunakan garis kecenderungan atau trendline dari program Microsoft Excel.

\section{Analisa Hubungan Jarak Pengukuran terhadap Rata - rata Tingkat Kebisingan}

Berdasarkan hasil analisa, dapat diketahui rata-rata kebisingan di Arboretum Sylva Untan dan halaman kantor Gubernur Kalbar berdasarkan empat kali pengulangan. Nilai rata - rata kebisingan di kedua lokasi tersebut kemudian dianalisa untuk diketahui hubungannya terhadap jarak pengukuran. 
Berikut disajikan data jarak pengukuran dan rata-rata tingkat kebisingan (Leq) di Arboretum Sylva Untan dalam Tabel 6.

Tabel 6. Jarak Pengukuran dan Rata-rata Tingkat Kebisingan (Leq) di Arboretum Sylva Untan

\begin{tabular}{|c|c|c|c|c|}
\hline Waktu & $\begin{array}{c}\text { Jarak } \\
(\mathrm{m})\end{array}$ & $\begin{array}{c}\text { Leq Plot I } \\
(\mathrm{dB})\end{array}$ & $\begin{array}{c}\text { Leq Plot II } \\
(\mathrm{dB})\end{array}$ & $\begin{array}{c}\text { Leq Plot III } \\
(\mathrm{dB})\end{array}$ \\
\hline $06.40-07.00$ & 2 & 76,37 & 78,03 & 78,27 \\
\hline $07.10-07.20$ & 50 & 61,19 & 61,42 & 61,20 \\
\hline $07.30-08.00$ & 98 & 52,48 & 54,10 & 54,41 \\
\hline
\end{tabular}

Data pada Tabel 6 kemudian diplotting ke dalam grafik Gambar 3 berikut.

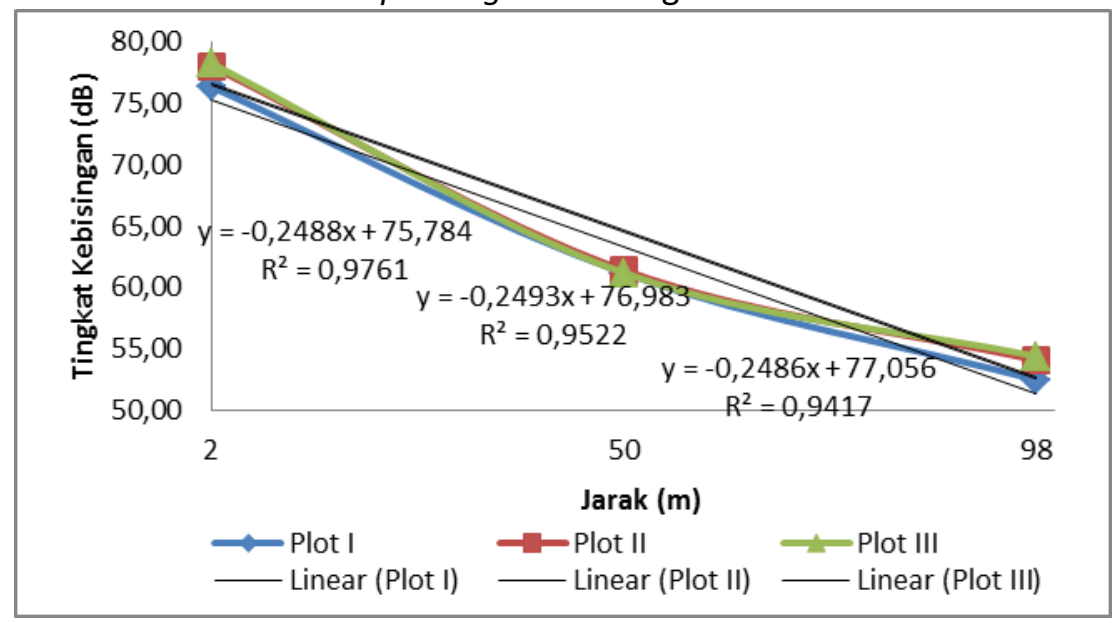

Gambar 3. Grafik Hubungan Linier antara Jarak Pengukuran dan Rata - rata Tingkat Kebisingan di Arboretum Sylva Untan

Grafik pada Gambar 3 menunjukkan bahwa arah hubungan antara variabel X (jarak) dan variabel $Y$ (tingkat kebisingan) adalah berlawanan arah (negatif) dan linier. Dalam hal ini, bila nilai $X$ naik maka nilai $Y$ turun, sebaliknya bila nilai $X$ turun maka nilai $Y$ secara linier naik. Dengan demikian, semakin jauh (naik) jarak pengukuran tingkat kebisingan maka semakin kecil (turun) tingkat kebisingannya. Grafik diatas menunjukkan hubungan linier antara jarak pengukuran dan rata - rata tingkat kebisingan di Arboretum Sylva Untan. Jarak pengukuran dan rata - rata tingkat kebisingan di lokasi Arboretum Sylva Untan memiliki hubungan atau korelasi yang sangat kuat ( $\mathrm{R}$ mendekati 1 ).

Setelah mengetahui hubungan antara jarak pengukuran dan rata-rata tingkat kebisingan (Leq) di Arboretum Sylva Untan, dilakukan analisa untuk mengetahui hubungan antara jarak pengukuran dan rata-rata tingkat kebisingan (Leq) di Halaman Kantor Gubernur Kalbar. Berikut disajikan data jarak pengukuran dan rata-rata tingkat kebisingan (Leq) di Halaman Kantor Gubernur Kalbar dalam Tabel 7.

Tabel 7. Jarak Pengukuran dan Rata - rata Tingkat Kebisingan (Leq) di Halaman Kantor Gubernur Kalbar

\begin{tabular}{|c|c|c|c|c|}
\hline Waktu & $\begin{array}{c}\text { Jarak } \\
(\mathrm{m})\end{array}$ & $\begin{array}{c}\text { Leq Plot I } \\
(\mathrm{dB})\end{array}$ & $\begin{array}{c}\text { Leq Plot II } \\
(\mathrm{dB})\end{array}$ & $\begin{array}{c}\text { Leq Plot III } \\
(\mathrm{dB})\end{array}$ \\
\hline $06.40-07.00$ & 2 & 78,11 & 77,82 & 77,79 \\
\hline $07.10-07.20$ & 50 & 63,67 & 64,70 & 64,03 \\
\hline $07.30-08.00$ & 98 & 60,28 & 61,99 & 60,87 \\
\hline
\end{tabular}

Data pada Tabel 7 kemudian diplotting ke dalam grafik Gambar $\mathbf{4}$ berikut. 


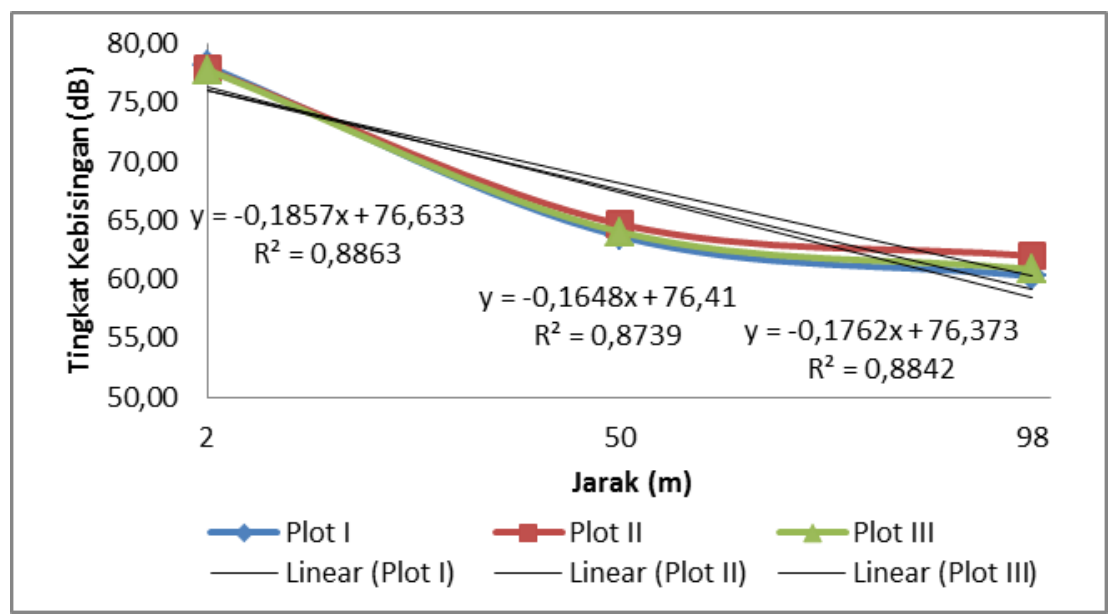

Gambar 4. Grafik Hubungan Linier antara Jarak Pengukuran dan Rata - rata Tingkat Kebisingan di Halaman Kantor Gubernur Kalbar

Grafik pada Gambar 4 menunjukkan hubungan antara jarak pengukuran dan rata - rata tingkat kebisingan di lokasi halaman kantor Gubernur Kalbar memiliki hubungan atau korelasi yang sangat kuat ( $\mathrm{R}$ mendekati 1$)$.

\section{KEMAMPUAN REDUKSI TINGKAT KEBISINGAN}

Nilai reduksi kebisingan dapat dihitung dengan rumus :

$$
N_{R}=K_{1}-K_{2}
$$

dan efektivitas reduksi dengan rumus :

$$
\text { Efektivitas Reduksi }=\frac{K_{1}-K_{2}}{K_{1}} \times 100 \%
$$

keterangan :

$\mathrm{N}_{\mathrm{R}}$ : nilai reduksi kebisingan $(\mathrm{dB}(\mathrm{A}))$

$\mathrm{K}_{1}$ : tingkat kebisingan di titik $1(\mathrm{~dB})$

$\mathrm{K}_{2}$ : tingkat kebisingan di titik $2(\mathrm{~dB})$

$\mathrm{K}_{3}$ : tingkat kebisingan di titik $3(\mathrm{~dB})$

Berikut disajikan data kemampuan reduksi dan efektivitas reduksi kebisingan berdasarkan empat kali pengukuran pada ketiga plot berukuran $180 \mathrm{~m}$ x $96 \mathrm{~m}$ di Arboretum Sylva Untan pada Tabel 8.

Tabel 8. Kemampuan Reduksi dan Efektivitas Reduksi Kebisingan di Arboretum Sylva Untan

\begin{tabular}{|c|c|c|c|c|c|c|c|c|c|}
\hline \multirow{3}{*}{ Plot } & \multicolumn{3}{|c|}{ Kebisingan } & \multicolumn{3}{c|}{ Reduksi Kebisingan } & \multicolumn{2}{c|}{ Efektivitas Reduksi } \\
\cline { 2 - 10 } & \multicolumn{3}{|c|}{ Titik Pengamatan } & $2-50 \mathrm{~m}$ & $50-98 \mathrm{~m}$ & $2-98 \mathrm{~m}$ & \multicolumn{2}{|c|}{} \\
\cline { 2 - 10 } & $\mathrm{K}_{1}(\mathrm{~dB})$ & $\mathrm{K}_{2}(\mathrm{~dB})$ & $\mathrm{K}_{3}(\mathrm{~dB})$ & $\begin{array}{c}\mathrm{K}_{1}-\mathrm{K}_{2} \\
(\mathrm{~dB})\end{array}$ & $\begin{array}{c}\mathrm{K}_{2}-\mathrm{K}_{3} \\
(\mathrm{~dB})\end{array}$ & $\begin{array}{c}\mathrm{K}_{1}-\mathrm{K}_{3} \\
(\mathrm{~dB})\end{array}$ & $\begin{array}{c}\mathrm{K}_{1}-\mathrm{K}_{2} \\
(\%)\end{array}$ & $\begin{array}{c}\mathrm{K}_{2}-\mathrm{K}_{3} \\
(\%)\end{array}$ & $\begin{array}{c}\mathrm{K}_{1}-\mathrm{K}_{3} \\
(\%)\end{array}$ \\
\hline 1 & 76,37 & 61,19 & 52,48 & 15,18 & 8,70 & 23,88 & 19,90 & 14,24 & 45,88 \\
\hline 2 & 78,03 & 61,42 & 54,10 & 16,61 & 7,33 & 23,94 & 21,25 & 11,96 & 44,48 \\
\hline 3 & 78,27 & 61,20 & 54,41 & 17,08 & 6,79 & 23,87 & 21,80 & 11,11 & 44,21 \\
\hline Jumlah & 232,67 & 183,80 & 160,99 & 48,87 & 22,82 & 71,69 & 62,95 & 37,32 & 134,58 \\
\hline Rerata & 77,56 & 61,27 & 53,66 & 16,29 & 7,61 & 23,90 & 21,00 & 12,44 & 44,86 \\
\hline
\end{tabular}

Berdasarkan hasil analisa, pada jarak 2 - 50 meter dari sumber suara, dengan jumlah vegetasi 449 jenis mampu mereduksi tingkat kebisingan sebesar $16,29 \mathrm{~dB}$ atau $21,00 \%$. Pada jarak 50 - 98 meter dari sumber suara, dengan jumlah vegetasi 317 jenis mampu mereduksi tingkat kebisingan sebesar 7,61 dB atau 12,44\%. Berdasarkan data tersebut, maka kemampuan 
reduksi di lokasi Arboretum Sylva Untan dengan area pengukuran 180 meter x 96 meter dengan jumlah vegetasi 716 jenis, mampu mereduksi tingkat kebisingan sebesar 23,90 dB atau $44,86 \%$.

Arboretum Sylva Untan sebagai ruang terbuka hijau di perkotaan berpengaruh besar bagi kawasan pendidikan yang berada di sekitarnya, yakni Universitas Tanjungpura dan Sd Al Azhar. Vegetasi di Arboretum Sylva Untan mampu mereduksi tingkat kebisingan dari aktivitas transportasi di jalan A. Yani Pontianak sehingga menjadikan kawasan pendidikan di sekitar, terkhusus Universitas Tanjungpura memenuhi standar baku tingkat kebisingan menurut Menteri Negara Lingkungan Hidup No.48/MenLH/XI/1996 untuk kawasan pendidikan, yaitu 55 $\mathrm{dB}$.

Setelah mengetahui kemampuan dan efektivitas reduksi kebisingan di lokasi Arboretum Sylva Untan, dilakukan analisa untuk mengetahui kemampuan dan efektivitas reduksi kebisingan di halaman Kantor Gubernur Kalbar. Data kemampuan reduksi dan efektivitas reduksi kebisingan berdasarkan empat kali pengukuran pada ketiga plot berukuran $180 \mathrm{~m} x$ 96m di halaman Kantor Gubernur Kalbar disajikan pada Tabel 9.

Tabel 9. Kemampuan Reduksi dan Efektivitas Reduksi Kebisingan di Halaman Kantor Gubernur Kalbar

\begin{tabular}{|c|c|c|c|c|c|c|c|c|c|}
\hline \multirow{3}{*}{ Plot } & \multicolumn{3}{|c|}{ Kebisingan } & \multicolumn{3}{c|}{ Reduksi Kebisingan } & \multicolumn{3}{c|}{ Efektivitas Reduksi } \\
\cline { 2 - 11 } & \multicolumn{2}{|c|}{ Titik Pengamatan } & $2-50 \mathrm{~m}$ & $50-98 \mathrm{~m}$ & $2-98 \mathrm{~m}$ & \multicolumn{2}{|c|}{} \\
\cline { 2 - 11 } & $\mathrm{K}_{1}(\mathrm{~dB})$ & $\mathrm{K}_{2}(\mathrm{~dB})$ & $\mathrm{K}_{3}(\mathrm{~dB})$ & $\begin{array}{c}\mathrm{K}_{1}-\mathrm{K}_{2} \\
(\mathrm{~dB})\end{array}$ & $\begin{array}{c}\mathrm{K}_{2}-\mathrm{K}_{3} \\
(\mathrm{~dB})\end{array}$ & $\begin{array}{c}\mathrm{K}_{1}-\mathrm{K}_{3} \\
(\mathrm{~dB})\end{array}$ & $\begin{array}{c}\mathrm{K}_{1}-\mathrm{K}_{2} \\
(\%)\end{array}$ & $\begin{array}{c}\mathrm{K}_{2}-\mathrm{K}_{3} \\
(\%)\end{array}$ & $\begin{array}{c}\mathrm{K}_{1}-\mathrm{K}_{3} \\
(\%)\end{array}$ \\
\hline 1 & 78,11 & 63,67 & 60,28 & 14,44 & 3,38 & 17,82 & 18,46 & 5,26 & 29,55 \\
\hline 2 & 77,82 & 64,70 & 61,99 & 13,12 & 2,71 & 15,82 & 16,77 & 4,04 & 25,57 \\
\hline 3 & 77,79 & 64,03 & 60,87 & 13,76 & 3,16 & 16,91 & 17,67 & 4,82 & 27,77 \\
\hline Jumlah & 233,71 & 192,39 & 183,15 & 41,32 & 9,24 & 50,56 & 52,90 & 14,13 & 82,89 \\
\hline Rerata & 77,90 & 64,13 & 61,05 & 13,77 & 3,08 & 16,85 & 17,63 & 4,71 & 27,63 \\
\hline
\end{tabular}

Pada kawasan halaman Kantor Gubernur Kalbar tingkat reduksi kebisingan sangat kecil, hal ini disebabkan tidak adanya penghalang suara/bunyi. Reduksi tingkat kebisingan di kawasan halaman Kantor Gubernur Kalbar terjadi karena adanya faktor jarak. Faktor jarak antara sumber suara dengan bangunan kantor Gubernur Kalbar mampu mengurangi tingkat kebisingan namun tidak seefektif dengan pengurangan tingkat kebisingan pada Arboretum Sylva Untan. Reduksi kebisingan karena faktor jarak ini, menjadikan kawasan kantor Gubernur Kalbar sebagai kawasan pemerintahan dan fasilitas umum memenuhi standar baku tingkat kebisingan yang telah ditetapkan oleh Menteri Negara Lingkungan Hidup No.48/MenLH/XI/1996 yaitu $60 \mathrm{~dB}$.

\section{E. REDUKSI TINGKAT KEBISINGAN SECARA ALAMIAH}

Jarak

Berdasarkan hasil analisa, total reduksi kebisingan sampai pada jarak 98 meter di Arboretum Sylva Untan sebesar 23,90 dB dan di halaman kantor Gubernur Kalbar sebesar $16,85 \mathrm{~dB}$. Dengan demikian dapat diketahui reduksi tingkat kebisingan tiap satu meter di masing-masing lokasi. Arboretum Sylva Untan mampu mereduksi tingkat kebisingan 0,24 $\mathrm{dB} /$ meter dan halaman kantor Gubernur Kalbar mereduksi tingkat kebisingan 0,17 dB/meter.

Tabel 10. Tingkat Kebisingan Tiap Jarak Pengukuran di Kedua Lokasi

\begin{tabular}{|c|c|c|c|c|c|c|}
\hline Lokasi Pengukuran & $\mathrm{K}_{1}(\mathrm{~dB})$ & $\mathrm{K}_{2}(\mathrm{~dB})$ & $\mathrm{K}_{3}(\mathrm{~dB})$ & $\begin{array}{c}\text { Reduksi } \\
\mathrm{K}_{1}-\mathrm{K}_{2}\end{array}$ & $\begin{array}{c}\text { Reduksi } \\
\mathrm{K}_{2}-\mathrm{K}_{3}\end{array}$ & $\begin{array}{c}\text { Reduksi } \\
\mathrm{K}_{1}-\mathrm{K}_{3}\end{array}$ \\
\hline Arboretum Sylva Untan & 77,56 & 61,27 & 53,66 & $16,29 \mathrm{~dB}$ & $7,61 \mathrm{~dB}$ & $23,90 \mathrm{~dB}$ \\
\hline Halaman Kantor Gubernur Kalbar & 77,90 & 64,13 & 61,05 & $13,77 \mathrm{~dB}$ & $3,08 \mathrm{~dB}$ & $16,85 \mathrm{~dB}$ \\
\hline
\end{tabular}




\section{Serapan Udara dan Angin}

Hasil pengukuran kondisi lingkungan rata-rata pada kedua lokasi pengukuran disajikan dalam Tabel 11.

Tabel 11. Kondisi Lingkungan Rata - rata di Lokasi Pengukuran

\begin{tabular}{|c|c|c|c|}
\hline Lokasi Pengukuran & Suhu $\left({ }^{\circ} \mathrm{C}\right)$ & Kecepatan Angin $(\mathrm{km} / \mathrm{h})$ & Arah Angin \\
\hline Arboretum Sylva Untan & $26,4-28,2$ & $3,1-4,8$ & Barat laut - tenggara \\
\hline Halaman Kantor Gubernur Kalbar & $24,7-30,1$ & $0,7-17,3$ & Barat laut - tenggara \\
\hline
\end{tabular}

Suhu udara di Arboretum Sylva Untan cenderung lebih rendah daripada di halaman kantor Gubernur Kalbar hal ini terjadi akibat perbedaan tipe penutupan tanah. Di lokasi Arboretum Sylva Untan yang ditumbuhi oleh banyak vegetasi mampu menyerap panas dari pancaran sinar matahari dan memantulkannya sehingga dapat menurunkan suhu dan iklim mikro. Namun kondisi suhu udara dan kelembaban relatif udara di Indonesia yang tinggi menyebabkan reduksi kebisingan karena serapan udara tidak dapat terjadi dengan baik. Arah angin bertiup menjauhi titik pengukuran atau pendengar, sehinggga bunyi diterima dengan kekuatan yang lemah.

\section{Permukaan Tanah}

Pada Arboretum Sylva Untan jenis permukaan berupa tanah, rerumputan dan vegetasi merupakan jenis permukaan yang lunak. Pada permukaan lunak, apabila bunyi merambat dari satu titik melalui permukaan lunak seperti ini, akan cukup signifikan menyerap bunyi yang merambat, sehingga bunyi yang diterima pada suatu titik berjarak tertentu dari sumber bunyi akan melemah kekuatannya.

Pada lokasi halaman kantor Gubernur Kalbar jenis permukaan berupa permukaan yang keras sehingga gelombang bunyi akan langsung dipantulkan oleh permukaan tersebut dan tingkat bunyi yang didengar menjadi kuat. Jika permukaan bumi atau suatu wilayah dilapisi dengan yang permukaan yang keras, maka permukaan tersebut tidak dapat menyerap gelombang bunyi yang merambat tapi justru dipantulkan, sehingga bunyi sampai ke suatu titik dengan jarak tertentu dari sumber bunyi menjadi lebih kuat (Mediastika, 2005).

\section{Halangan/Barrier}

Pada Arboretum Sylva Untan terdapat penghalang berupa vegetasi yang dapat memotong garis perambatan gelombang suara dari sumber ke penerima. Sedangkan pada lokasi halaman kantor Gubernur Kalbar tidak terdapat halangan/barrier sehingga tidak ada media untuk menahan atau mengurangi merambatnya kebisingan dari jalan ke bangunan kantor Gubernur.

\section{KESIMPULAN}

Kawasan Arboretum Sylva Untan dengan area pengukuran 180 meter x 96 meter dengan jumlah vegetasi 716 jenis, mampu mereduksi tingkat kebisingan sebesar 23,90dB dan efektivitas reduksi sebesar 44,86\%. Kemampuan reduksi tersebut menjadikan kawasan Universitas Tanjungpura memenuhi standar baku tingkat kebisingan berdasarkan Keputusan Menteri Negara Lingkungan Hidup No.48 tahun 1996 untuk kawasan pendidikan, yaitu 55dB. Dan pada lokasi halaman kantor Gubernur Kalbar dengan kemampuan reduksi tingkat kebisingan sebesar 16,85dB menjadikan kawasan kantor Gubernur Kalbar memenuhi standar baku tingkat kebisingan untuk kawasan fasilitas umum dan pemerintahan, yaitu $60 \mathrm{~dB}$. 


\section{UCAPAN TERIMA KASIH}

Terima kasih penulis ucapkan kepada seluruh pihak yang telah membantu dalam penyelesaian penelitian ini, terkhusus kepada kedua orang tua. Terima kasih kepada bapak Dr. Ir. H. Syafaruddin AS, M.M dan ibu Sarma Siahaan, S.Si, M.Si selaku dosen pembimbing serta kepada ibu Sumiyattinah, S.T, M.T dan bapak Robby Irsan, S.T, M.Si selaku dosen penguji yang telah memberikan masukan dan koreksi yang sangat bermanfaat dalam penyelesaian penelitian ini.

\section{REFERENSI}

Arlan, Mirani. 2011. Pengaruh Volume Kendaraan terhadap Kebisingan dan Pemetaan Kebisingan Menggunakan Perangkat Lunak Arcview Dikelurahan Pondok Cina, Depok, Akibat Kegiatan Transportasi di Jalan Margonda Raya. Program Studi Teknik Lingkungan. Fakultas Teknik. Depok : Universitas Indonesia.

Handayani, Dini Rr. 2003. Pengkajian Faktor - Faktor Tingkat Kebisingan Jalan Perkotaan. Bandung. Puslitbang Jalan dan Jembatan.

Keputusan Menteri Negara Lingkungan Hidup Nomor : KEP-48/MENLH/11/1996 Tentang Baku Tingkat Kebisingan.

Mediastika, E. Christina. 2005. Akustika Bangunan : Prinsip-prinsip dan Penerapannya di Indonesia. Jakarta : Penerbit Erlangga.

Pusat Pendidikan dan Pelatihan MENLH. 2009. Modul Diktat Pengendalian Pencemaran Udara. Edisi Pertama. Jakarta

Widyantoro, Bagus., dan Razif, Mohammad. 2013. Pemetaan Tingkat Kebisingan Akibat Transportasi Dikaitkan dengan Tata Guna Lahan di Jl. Arif Rachman Hakim Surabaya. Jurusan Teknik Lingkungan. Fakultas Teknik Sipil dan Perencanaan. Surabaya : Institut Teknologi Sepuluh November. 